\title{
Pengaruh dan Pola Aktivitas Penggunaan Internet serta Media Sosial pada Siswa SMPN 52 Surabaya
}

\author{
Astrid Kurnia Sherlyanita $^{1)}$, Nur Aini Rakhmawati ${ }^{2)}$ \\ ${ }^{1,2)}$ Jurusan Sistem Informasi, Fakultas Teknologi Informasi, Institut Teknologi Sepuluh Nopember \\ Jl. Raya ITS, Surabaya, 60111, Jawa Timur, Indonesia \\ ${ }^{1)}$ sherlyanita13@mhs.is.its.ac.id \\ ${ }^{2)}$ nur.aini@is.its.ac.id
}

\begin{abstract}
Abstrak- Perkembangan fungsi dari internet membuat internet dapat diakses bagi semua kalangan. Akhir-akhir ini, beberapa penelitian membuktikan bahwa sebagian besar pengguna internet adalah kalangan remaja. Berkembangnya media sosial secara mendunia secara tidak langsung memiliki pengaruh besar terhadap penggunaan internet bagi remaja. Fokus pada paper ini adalah penelitian seberapa besar pengaruh penggunaan internet dan media sosial bagi remaja ditinjau dari beberapa aspek serta pola aktivitas penggunaan sosial media pada remaja. Penelitian dilakukan terhadap 44 siswa dan 2 (dua) guru SMPN 52 Surabaya. Hasil survey kemudian dianalisis apakah para siswa memiliki pengetahuan yang cukup terhadap hal-hal yang sebaiknya dilakukan dan tidak berkaitan dengan keamanan dalam penggunaan media sosial. Didapatkan hasil bahwa siswa SMPN 52 Surabaya secara umum sudah dapat menentukan penggunaan internet secara baik, baik untuk sarana pembelajaran maupun fungsi hiburan seperti media sosial, di mana waktu interaksi siswa pada interaksi langsung di kehidupan sehari-hari dan waktu interaksi pada media sosial sudah seimbang dan sesuai dengan porsinya. Serta dapat diketahui bahwa para siswa SMPN 52 Surabaya sudah dapat mengetahui hal-hal dasar yang perlu diterapkan keamanan, seperti pembatasan privasi dan sharing hanya untuk orang yang dikenal.
\end{abstract}

Kata Kunci- Internet, Media Sosial, Remaja

Abstract-Nowdays, internet is accessable for everyone. Previous studies prove that the majority of internet users are teenagers. Development of worldwide social media indirectly have a major influence on the use of the internet for teen. The focus of this paper is to investigate the impact of the Internet and social media for teens. We evaluated from several aspects as well as social media usage patterns of activity in adolescents. The study was conducted on $\mathbf{4 4}$ students and two teachers at SMPN 52 Surabaya. The results then analyzed whether the students have sufficient knowledge of the things that should be done and not related to safety in the use of social media. The results showed that the most of students at SMPN 52 Surabaya generally been able to determine the use of the Internet, both for the means of learning and entertainment functions such as social media, where the interaction time students on direct interaction in daily life and time interaction on social media is already balanced and accordance with the portions. As well as it can be seen that the students of SMPN 52 Surabaya already be aware of the basic things that need to be applied to security, such as restrictions on privacy and sharing only to people you know.

Keywords-Internet, Social Media, Teen

Article history:

Received 12 February 2016; Accepted 28 March 2016; Available online 30 April 2016

\section{PENDAHULUAN}

Pengguna internet telah meningkat setiap waktu. Internet adalah sebuah sistem informasi global yang terhubung secara logika oleh address yang unik secara global yang berbasis pada Internet Protocol (IP), mendukung komunikasi dengan menggunakan TCP/IP, menyediakan, menggunakan, dan membuatnya bisa diakses baik secara umum maupun khusus (Greenlaw \& Hep, 2001). Sumber lain mendefinisikan internet sebagai sebuah jaringan besar yang menghubungkan jaringan komputer baik dari organisasi bisnis, organisasi pemerintahan, dan sekolah-sekolah dari seluruh dunia secara langusung dan cepat (Turban, Rainer, \& Potter, 2005). Penggunanya dapat mencakup semua usia, dari kalangan kanak-kanak sampai dewasa. Begitu pula dengan dunia pendidikan, internet telah menjadi salah satu fasilitator utama dalam pelaksanaan proses belajar mengajar pada institusi-institusi pendidikan di seluruh penjuru dunia. Digitalisasi bahkan telah diimplementasikan pada institusi pendidikan di negaranegara berkembang di seluruh dunia, seperti pengajaran menggunakan presentasi digital, pengumpulan tugas secara online dan lain sebagainya. Siswa maupun pengajar secara tidak langsung dituntut untuk menguasai berbagai alat maupun perangkat lunak teknologi informasi mengingat perangkat keras dan perangkat lunak tersebut sebagai fondasi dari berjalannya sebuah teknologi informasi.

Seiring berjalannya waktu, perkembangan fungsi dan tujuan internet tidak hanya diperuntukkan untuk keperluan edukasi dan komersial, melainkan dikembangkan lebih lanjut untuk fungsi komunikasi yang disebut dengan media sosial. Media sosial adalahsebuah kelompok aplikasi berbasis internet yang dibangun di atas dasar teknologi Web 2.0 dan mendukung penciptaan serta pertukaran usergenerated content, juga memungkinkan penggunanya untuk berpartisipasi, berbagi dalam komunikasi dan 


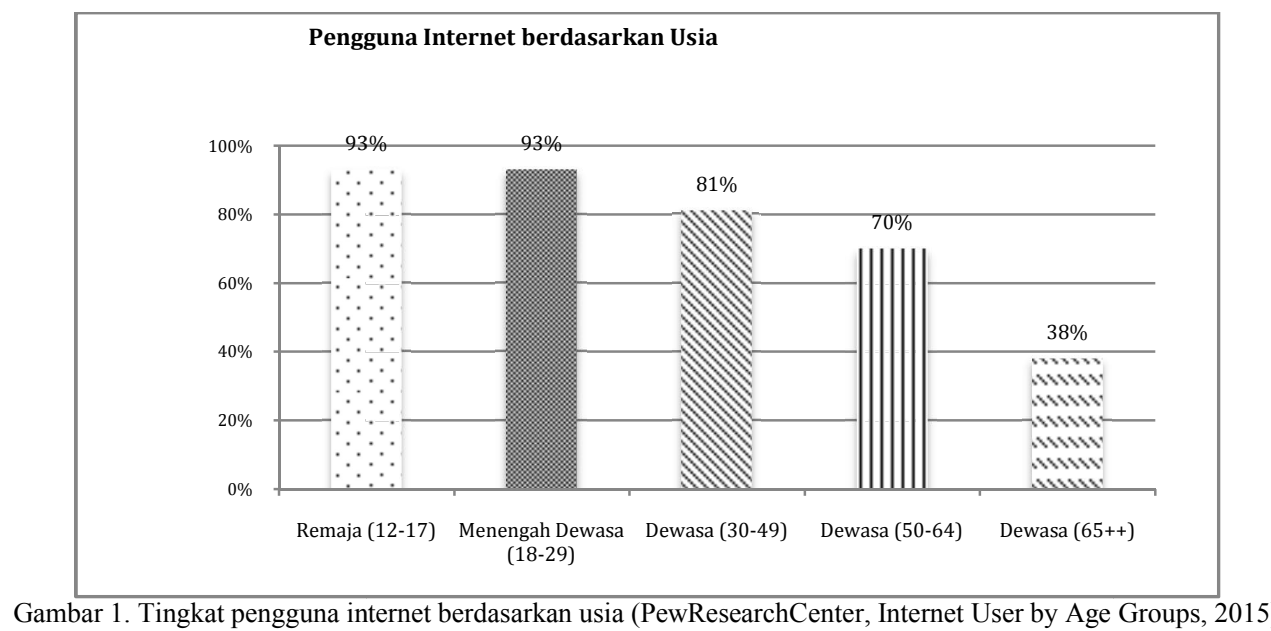

dikemas dalam bentuk yang beragam, baik blog, jejaring sosial, forum, wiki dan lain-lain (Kaplan \& Haenlein, 2010).

Adapun pengguna internet di seluruh dunia telah mencapai angka 31,7 miliar dan dari tahun ke tahun jumlah pengguna internet tumbuh hingga 7,6 persen. Sedangkan untuk pengguna media sosial sendiri mencapai angka 2,2 miliar dengan pengguna mobile mencapai 3,7 miliar. Hal ini yang menjadi fokus utama dalam pelaksanaan penelitian ini adalah berkembang pesatnya jumlah pengguna internet utamanya media sosial yang menurut Kemenkominfo Republik Indonesia, di Indonesia sendiri 80 persen di antaranya terdiri dari remaja 15-19 tahun. Sedangkan pada kenyataannya, remaja menggunakan internet tidak hanya untuk kebutuhan edukasi saja, melainkan dipergunakan juga untuk hiburan, belanja, media sosial dan lain sebagainya (Noviandari, 2015).

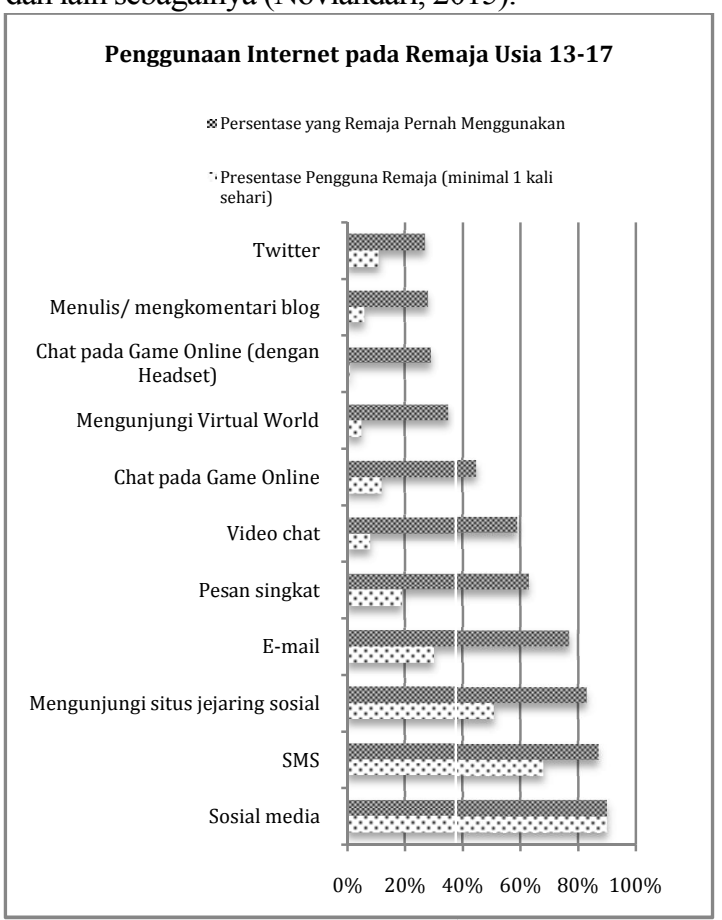

Gambar 2. Penggunaan internet pada remaja usia 13-17 tahun (PewResearchCenter, Use of Social and Digital Communication, 2015)
Menurut pewinternet.com seperti yang ditunjukan pada gambar 1, pengguna internet di seluruh dunia didominasi oleh kalangan remaja usia 12-17 tahun dan remaja menuju dewasa berusia 18-29 tahun yang sama-sama memiliki presentase 93 persen.

Dari penelitian penggunaan internet oleh kalangan remaja (13-17 tahun), media sosial memiliki pengaruh besar dalam penggunaan internet bagi remaja. Di antara 11 aktivitas penggunaan internet oleh remaja pada Gambar 2, 7 (tujuh) di antaranya merupakan aktivitas penggunaan media sosial (used any social media, visited a social-networking site, instant messaged, video chat, virtual world, written/commented on a blog dan twitter)

Penggunaan internet oleh remaja yang didominasi dengan penggunaan media sosial juga terjadi di Indonesia. Hal tersebut ditunjukkan dengan hasil survey yang dilakukan oleh Statista melalui halaman websitenya dengan judul Penetration of leading social networks in Indonesia terhitung sampai kuartal keempat tahun 2014.

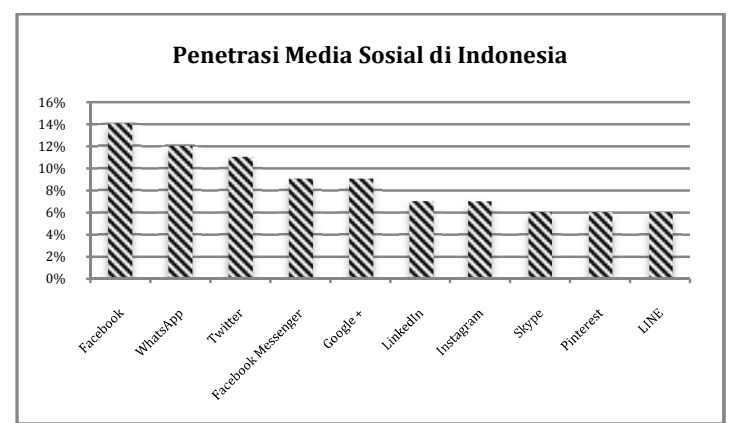

Gambar 3. Grafik penetrasi media sosial di Indonesia (Statista, 2015)

Media sosial dengan penetrasi tertinggi di Indonesia ditempati oleh Facebook dengan presentase pengguna $14 \%$ dari keseluruhan pengguna. Kemudian, disusul dengan WhatsApp, Twitter, Facebook Messenger, Google+, LinkedIn, Instagram, Skype, Pinterest dan urutan terakhir ditempati LINE dengan presentase $6 \%$. 
Dalam pencarian berita di Google Indonesia, dengan memasukkan kata kunci "internet remaja" ditemukan sekitar 522.000 hasil dan sebagian besar merupakan berita bernada negatif seperti bahaya internet yang dapat berupa pornografi, peretasan, penyadapan, transaksi narkoba, terorisme, penipuan dan lain sebagainya. Sedangkan untuk kata kunci "media sosial remaja" ditemukan 127.000 hasil. Di mana hasilnya didominasi oleh dampak-dampak yang dihasilkan dari penggunaan media sosial pada kalangan remaja, bahkan sampai ada yang menimbulkan kecelakaan dan kematian.Adapun tujuan dari penelitian ini adalah mengetahui pengaruh dan pola aktivitas pada media sosial serta terhadap remaja dan hubungan interaksi pada kehidupan sehari-hari.

\section{STUDI TERKAIT}

Perilaku dan kebiasaan pada generasi millennium yang berusia 18 sampai 29 tahun berkaitan dengan kepemilikan gadget, game console, laptop pada remaja, data statistik penggunaan jaringan nirkabel sesuai demografi, tingkat antusiasme remaja terhadap media sosial, tingkat penyebarluasan konten pada media sosial (Lenhart, Purcell, Smith, \& Zickuhr, 2010).

Regulasi keselamatan anak-anak pada jaringan sosial yang memungkinkan provider untuk memastikan anak-anak tersebut cukup umur untuk mengakses website, kesadaran akan pesan keselamatan yang didukung oleh setting privasi, perlindungan informasi pribadi (Livingstone, Ólafsson, \& Staksrud, 2013).

Teknologi sosial yang memotivasi dosen-dosen di universitas untuk menggunakan teknologi untuk Online Social Networking (OSN). Teknologi tersebut dapat meningkatkan metode pembelajaran. Paper ini berfokus pada penggunaan OSN untuk interaksi mahasiswa-mahasiswa dan mahasiwadosen (Hamid, Waycott, Kurnia, \& Chang, 2015)

\section{METODE}

\section{A. Pengumpulan Data}

Metode yang digunakan pada penelitian ini adalah menggunakan kuesioner yang dilakukan pada saat sosialisasi mengenai Internet Sehat pada SMPN 52 Surabaya yang bertempat di J1. Medokan Semampir, Gang Kelurahan No. 124, Medokan Semampir Surabaya pada tanggal 29 September 2015. Dengan audiens sebanyak 44 siswa dan 2 (dua) guru pada SMPN 52 Surabaya. Kuesioner yang diperuntukkan untuk siswa berisi pertanyaan tertutup sejumlah 14 pertanyaan dan 2 (dua) pertanyaan tertutup. Sedangkan, kuesioner yang ditujukan untuk guru berisi pertanyaan tertutup sejumlah 9 (sembilan) pertanyaan tertutup dan 3 (tiga) pertanyaan terbuka. Pertanyaan yang terdapat pada kuesioner secara garis besar mengenai internet, sosial media, kejahatan pada internet, hubungan internet pada proses belajar mengajar antara guru dengan siswa dan aturan-aturan tertulis mengenai informasi dan transaksi elektronik.

Pembuatan kuesioner didasarkan dari paperyang membahas tentang praktik penggunaan jejaring sosial pada kalangan di bawah umur yang kemudian digagasnya sebuah regulasi keselamatan anak-anak pada jaringan sosial yang memungkinkan provider untuk memastikan anakanak tersebut cukup umur untuk mengakses website, kesadaran akan pesan keselamatan yang didukung oleh setting privasi, perlindungan informasi pribadi (Livingstone, Ólafsson, \& Staksrud, 2013). Penggunaan paper ini sebagai acuan pembuatan kuesioner adalah keterkaitan tujuan analisis yakni mengetahui adanya pengaruh dan pola aktivitas penggunaan internet serta media sosial pada siswa SMPN 52 Surabaya dengan praktik-praktik yang terjadi ketika kalangan usia di bawah umur mengakses jejaring sosial yang dijelaskan dalam paper acuan tersebut. Praktikpraktik dan pola aktivitas yang pernah terjadi diolah menjadi ke dalam bentuk pertanyaan untuk mengetahui terjadinya perubahan dan pengaruh pada pola aktivitas penggunaan internet serta media sosial.

Pengumpulan data dilakukan secara manual dengan cara perekapan satu per satu hasil kuesioner dan direkap jawaban per pertanyaannya satu per satu. Pengumpulan data menggunakan tools Microsoft Excel dan dilakukan rekap grafik presentase jawaban per pertanyaan.

\section{HASIL ANALISIS}

Hasil analisis dilakukan terhadap beberapa aspek yang dilakukan para remaja terkait media sosial dan pengaruhnya terhadap interaksi sosial pada kehidupan sehari-hari.

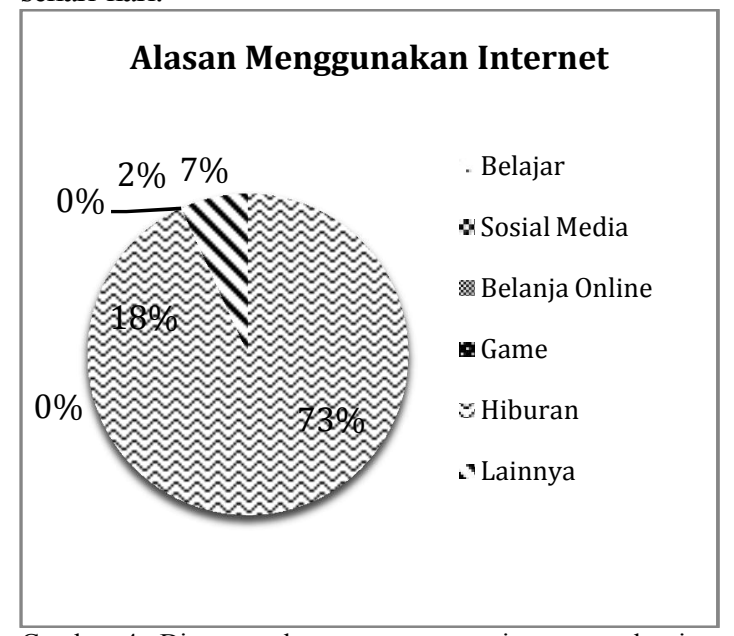

Gambar 4. Diagram alasan penggunaan internet pada siswa SMPN 52 Surabaya

Gambar 4 menunjukkan alasan para siswa SMPN 52 Surabaya untuk menggunakan internet. Hasil menunjukkan bahwa walaupun penggunaan media sosial di kalangan remaja menunjukkan angka yang tinggi pada berbagai berita dan literatur, namun lain hal dengan penggunaan internet bagi SMPN 52 Surabaya, 
di mana tujuan terbanyak para siswa menggunakan internet ialah untuk tujuan pembelajaran atau edukasi. Media sosial bahkan menempati peringkat ketiga setelah belanja online.

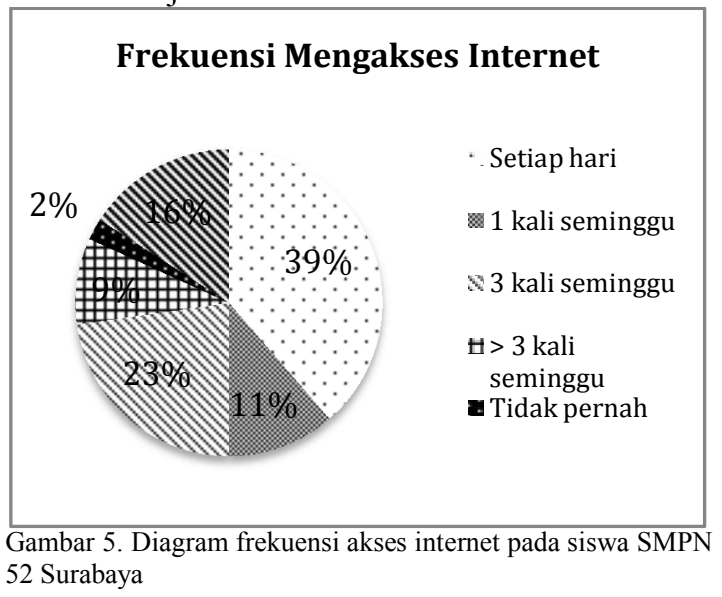

Frekuensi para siswa SMPN 52 Surabaya dalam mengakses internet menunjukkan angka tertinggi pada frekuensi setiap hari seperti ditunjukkan pada gambar 5. Hal ini sesuai dengan riset yang telah dilakukan sebelumnya bahwa remaja memiliki tingkat ketergantungan yang sangat tinggi terhadap internet, baik untuk tujuan belajar, media sosial, belanja online, game maupun hiburan lainnya sehingga hampir dapat dipastikan sebagian besar remaja akan mengakses internet setiap hari. Namun, hal yang tidak diduga terjadi pada siswa SMPN 52 Surabaya, di mana terdapat 2 persen dari seluruh audiens sosialisasi yang belum pernah mengakses internet sama sekali.

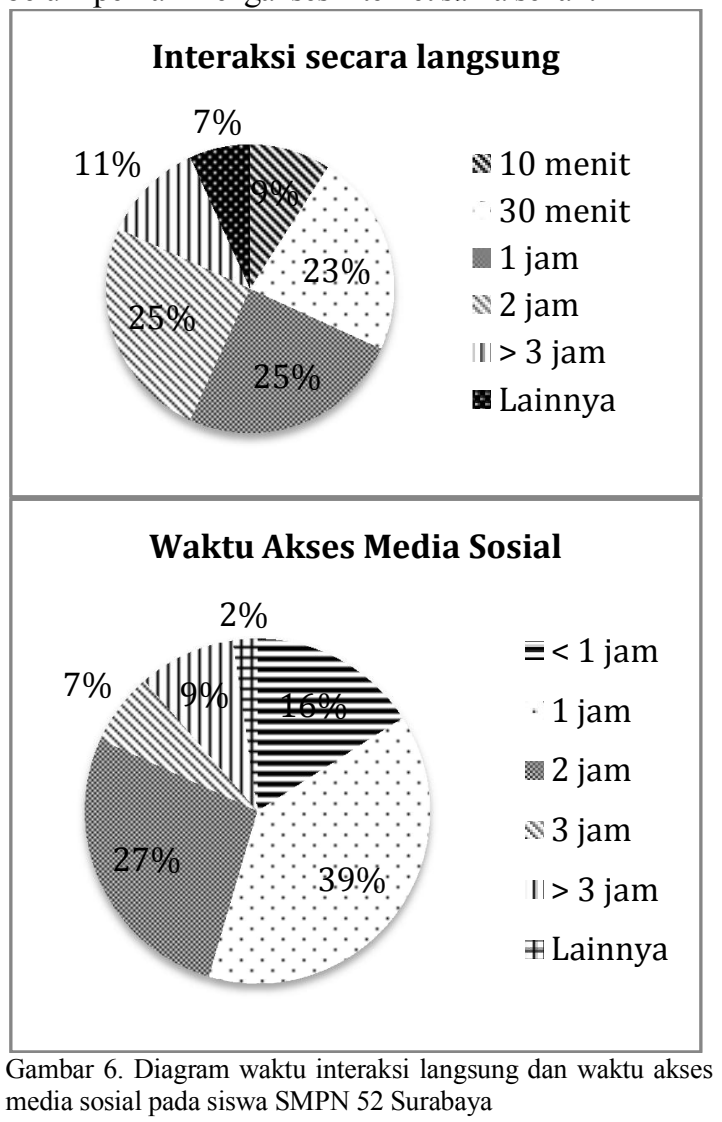

Perbandingan antara interaksi secara langsung pada kehidupan sehari-hari dibandingkan dengan waktu akses media sosial ditunjukkan pada gambar 6 . Interaksi para siswa SMPN 52 Surabaya yang dilakukan secara langsung pada kehidupan sehari-hari sebagian besar berkisar pada angka 1-2 jam sehari. Angka tersebut masih dapat terbilang seimbang dibandingkan waktu para siswa SMPN 52 Surabaya mengakses media sosial, dimana sebagian besar siswa mengakses media sosial selama 1 jam. Sehingga, interaksi yang dilakukan para siswa SMPN 52 Surabaya di kehidupan sehari-hari dan media sosial internet masih dalam ambang batas wajar, di mana waktu akses media sosial tidak lebih banyak daripada waktu interaksi di kehidupan sehari-hari.

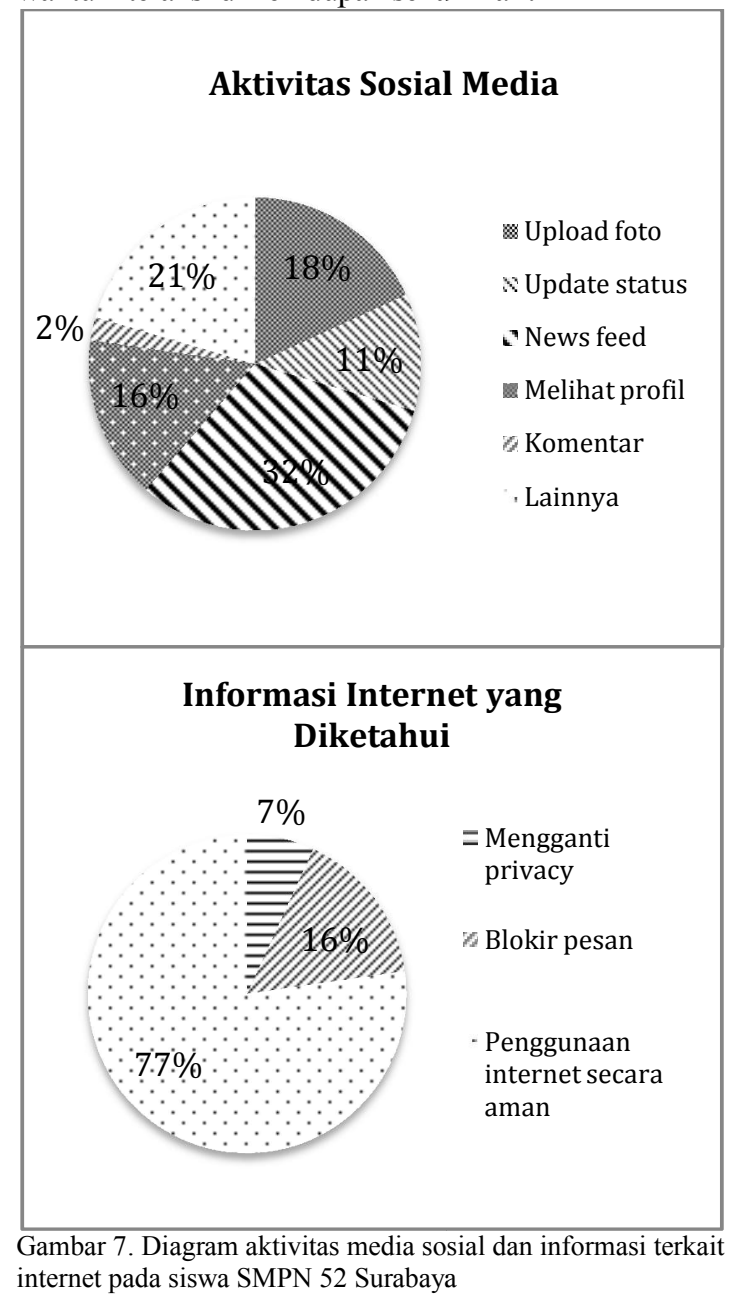

Gambar 7 menunjukkan aktivitas sosial media yang paling sering dilakukan. Siswa SMPN 52 Surabaya paling sering melihat news feed atau timeline, kemudian dilanjutkan dengan upload, melihat profil, kemudian yang terakhir adalah komentar. Fenomena ini seringkali ditemukan pada kejadian sehari-hari, di mana pengguna media sosial tertentu seringkali melihat news feed atau timeline tanpa memberikan respon atau komentar dan hanya menjadi silent reader.

Pengetahuan para siswa terhadap informasi penting penggunaan internet tertinggu terdapat pada kategori penggunaan internet secara aman. Kategori 
pengetahuan terendah terdapat pada mengganti privacy, padahal kategori ini merupakan kategori informasi yang harus diketahui dalam penggunaan media sosial. Angka pengetahuan siswa SMPN 52 Surabaya terhadap privacy hanya 7 persen.

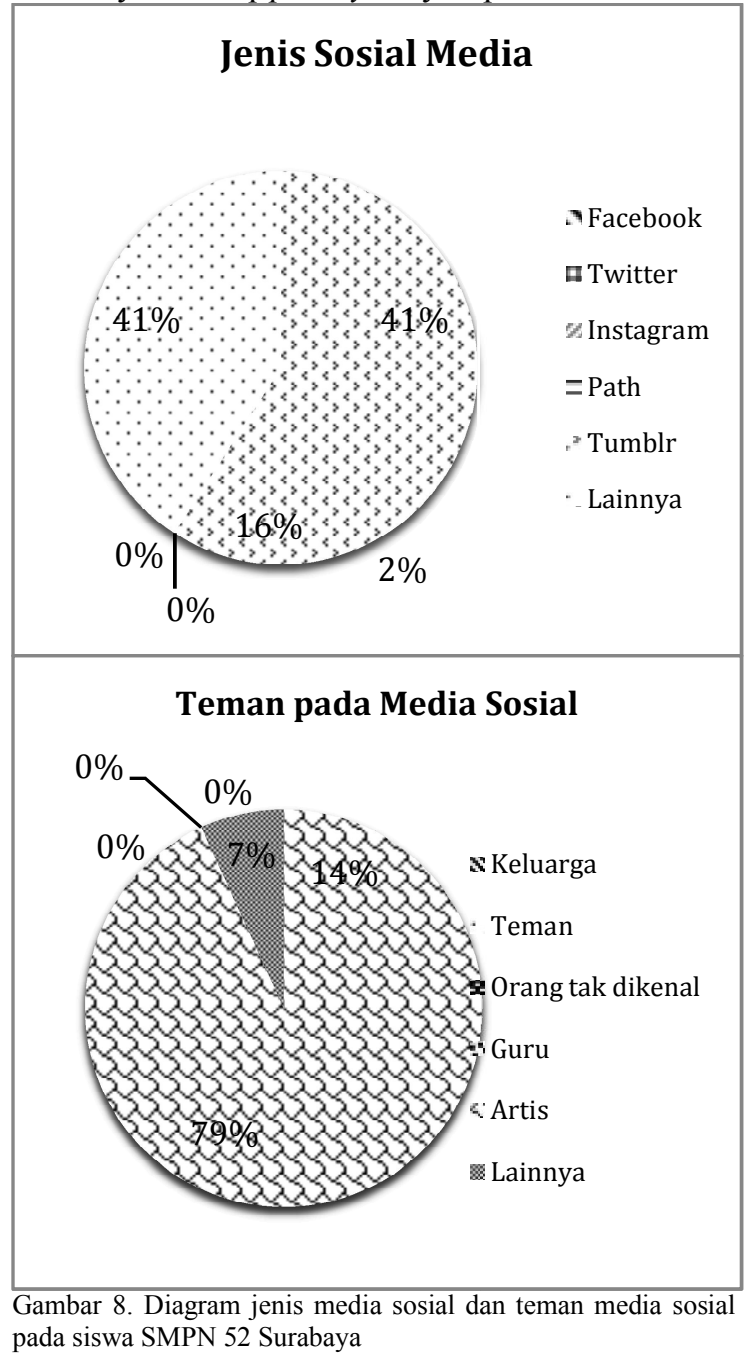

Jenis sosial media yang paling sering digunakan oleh para siswa SMPN 52 Surabaya adalah Facebook dengan angka 41 persen. Di mana media sosial kedua yang paling sering digunakan adalah instagram. Twitter, path dan tumblr memiliki angka yang rendah. Bahkan untuk path dan tumblr memiliki angka 0 persen. Fenomena ini terjadi pada siswa SMPN 52 Surabaya yang notabene berusia antara 12-15 tahun dan terbilang cukup unik, mengingat belakangan ini platform path lebih memiliki banyak pengguna yang login secara berkala jika dibandingkan dengan Facebook. Selain itu, path memiliki karakteristik privasi yang lebih aman jika dibandingkan dengan platform lainnya, dikarenakan circle-nya yang terbatas dan tidak terpublikasi secara luas.

Jaringan yang pada media sosial para siswa SMPN 52 Surabaya terbilang sudah sesuai dengan kriteria keamanan dan privasi sebuah pertemanan dalam media sosial. Di mana 79 persen pertemanan yang terjalin di media sosial merupakan pertemanan dengan teman yang dikenal dan 14 persen dengan keluarga. Hal ini mempengaruhi keamanan para siswa SMPN 52 Surabaya dalam penggunaan media sosial, di mana media sosial sudah seharusnya dibatasi hanya dengan orang yang dikenal dan terpercaya.

Pengaturan halaman pribadi media sosial siswa SMPN 52 Surabaya diatur secara pribadi 41 persen. Pengaturan pribadi adalah di mana hanya teman dari pengguna yang dapat melihat aktivitas media sosial. Urutan kedua adalah pengaturan setengah pribadi sebesar 34 persen yang berarti hanya teman dari jaringan pertemanan yang dapat melihat. Dan terakhir yakni pengaturan umum yang mana semua orang dapat melihat aktivitas media sosial pengguna sebesar 25 persen.

Sedangkan, informasi pada halaman profil yang terbilang fatal untuk disebarluaskan seperti nomor telepon, alamat tidak disebarluaskan oleh siswa SMPN 52 Surabaya dan tidak menyalahi aturan keamanan privasi media sosial. Siswa SMPN 52 Surabaya sedikitnya sudah mengerti apa yang dapat disebarluaskan dan tidak.

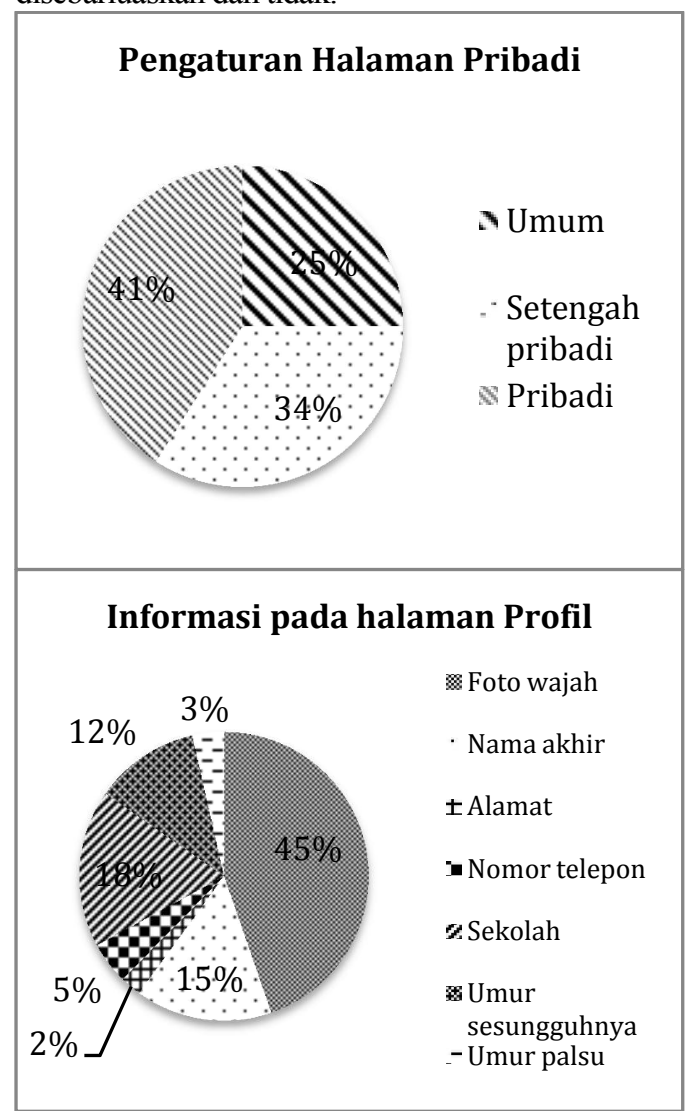

Gambar 9. Diagram pengaturan halaman pribadi dan informasi halaman profi media sosial pada siswa SMPN 52 Surabaya

\section{KESIMPULAN}

Dari penelitian yang telah dilakukan, didapatkan beberapa hasil bahwa siswa SMPN 52 Surabaya sudah dapat menentukan penggunaan internet secara baik, baik untuk sarana pembelajaran maupun fungsi hiburan seperti media sosial. Meskipun, sebagian besar siswa SMPN 52 Surabaya memiliki frekuensi akses internet setiap hari seperti remaja pada umumnya, 
namun waktu interaksi siswa pada interaksi langsung di kehidupan sehari-hari dan waktu interaksi pada media sosial sudah seimbang dan sesuai dengan porsinya. Aktivitas yang dilakukan pada media sosial umumnya adalah untuk mencari tahu dan tetap mengikuti apa yang ada di news feed atau time line, karena hanya sebagian kecil dari para siswa yang gemar untuk mengomentari dan memberi respon terhadap aktivitas pengguna lain di media sosial. Dari sekian media sosial yang ada, Facebook masih menjadi sarana media sosial yang paling sering digunakan oleh para siswa dengan mayoritas pertemanan pada media sosial tersebut adalah teman dan keluarga.

Secara garis besar keseluruhan, para siswa sudah mengetahui mengenai hal-hal dasar yang perlu diterapkan pada media sosial terkait keamanan, misalnya membatasi pertemanan hanya untuk orang yang dikenal, pengaturan halaman pribadi menjadi hanya dapat diakses oleh teman pada media sosial dan pembatasan informasi yang disebarluaskan pada media sosial.

\section{DAFTAR PUSTAKA}

Greenlaw, R., \& Hep, E. (2001). Inline/online: fundamentals of the internet and the world wide web. Osborne: McGraw-Hill.

Hamid, S., Waycott, J., Kurnia, S., \& Chang, S. (2015). Understanding students' perceptions of the benefits of online social networking use for teaching and learning. The Internet and Higher Education , 26, 1-9.
Kaplan, A. M., \& Haenlein, M. (2010). Users of the world, unite! The challenges and opportunities of Social Media. Business horizons , 53 (1), 5968.

Lenhart, A., Purcell, K., Smith, A., \& Zickuhr, K. (2010, Februari 3). Social Media and Young Adults. Dipetik Oktober 22, 2015, dari http://www.pewinternet.org/2010/02/03/socialmedia-and-young-adults/

Livingstone, S., Ólafsson, K., \& Staksrud, E. (2013). Risky social networking practices among "underage" users: lessons for evidence-based policy. Journal of Computer-Mediated Communication , 18 (3), 303-320.

Noviandari, L. (2015, Agustus 18). Statistik Pengguna Internet dan Media Sosial Terbaru 2015. Dipetik Oktober 22, 2015, dari techinasia: https://id.techinasia.com/

PewResearchCenter. (2015). Internet User by Age Groups. Dipetik Oktober 22, 2015, dari http://www.pewinternet.org/

PewResearchCenter. (2015). Use of Social and Digital Communication. Dipetik Oktober 22, 2015, dari https://pewinternet.org/

Statista. (2015). Penetration of Leading Social Networks in Indonesia as of 4th Quarter 2015. Dipetik Oktober 22, 2015, dari https://statista.com/

Turban, E., Rainer, R. K., \& Potter, R. E. (2005). Introduction to Information Technology. New Jersey: John Wiley \& Sons. 